\title{
A New Record for Flora of Turkey; Artemisia oliveriana J.Gay ex Besser (Asteraceae)
}

\section{Türkiye Florası için Yeni Bir Tür Kaydı; Artemisia oliveriana J.Gay ex Besser (Asteraceae)}

\author{
Research Article
}

\section{Mehmet Firat}

Department of Biology, Faculty of Education, Yüzüncü Yıl University, Van, Turkey.

\section{A B S TR ACT}

rtemisia oliveriana (Asteraceae) is described as a new record to the Flora of Turkey (C9, Hakkâri). Detailed morphological description, photos, distribution map of this new record has been given.

\section{Key Words}

New record, Artemisia oliveriana, Hakkâri.

\section{ÖZET}

rtemisia oliveriana (Asteraceae) türü Türkiye Florası için ilk kez (C9, Hakkâri) kaydedilmiştir. Yani kaydın ayrıntılı morfolojik betimi, fotoğrafları ve yayılış haritası verilmiştir.

\section{Anahtar Kelimeler}

Yeni kayıt, Artemisia oliveriana, Hakkâri.

Article History: Received: Jun 22, 2015; Revised: Dec 24, 2015; Accepted: Mar 20, 2016; Available Online: Apr 1, 2016. DOI: $10.15671 /$ HJBC.20164418126

Correspondence to: M. Fırat, Department of Biology, Faculty of Education, Yüzüncü Yıl University, Van, Turkey. 


\section{INTRODUCTION}

The he genus Artemisia L., which comprises more than 500 species, is one of the largest genera of the family Asteraceae [1-4]. Although the genus Artemisia is mainly distributed in the northern hemisphere, the genus is represented by few species in southern hemisphere. According to the investigation of [5] Asia is one of the important gene centres of the genus.

Medical usage; foodstuff and allergenic properties of the genus got genus study well $[6,7]$. Also having polyploidy make the genus interesting for the cytogenetic and karyological studies.

The studies, such as cytogenetic and karyological studies which are made by [813] about genus Artemisia showed that genus divided into 5 subgenera as Artemisia Less. Absinthium (Mill.) Less., Dracunculus (Bess.) Rydb., Seriphidium (Bess.) Rouy., and Tridentatae (Rydberg) McArthur but lack of molecular studies make subgeneric classification of the genus difficult [14].

In Turkey, genus is represented by 26 taxa into 4 subgenera $[15,16]$. But there is a debate about some Turkish taxa such as Artemisia santonicum L. subsp. patens (Neilr.) K.M.Perss. [17]. Also a new species, Artemisia bashkalensis Kurşat \& Civelek, has recorded as a new species to the Turkish flora recently [18].

\section{MATERIALS AND METHODS}

Artemisia oliveriana J.Gay ex Besser, the material of this study, was collected in Berçelan Plateau (Figure 1), Hakkâri in October 2014. According to the description of Flora of Turkey and the East Aegean Islands [19], Flora of Turkey and the East Aegean Islands (Supplement) [20] it was concluded that collected materials were new record for Turkey flora. Detailed investigation of liteliteratures $[16,21]$ showed that collected materials have been described as Artemisia oliveriana from Flora Iranica. Collected materials were deposited at the Herbarium of Yüzüncü YII University Science Faculty (VANF).

\section{Description}

Artemisia oliveriana J.Gay ex Besser, Prodr. 6: 101 (1837). (Figure 2).

Syn.: A. serotina Bunge, Beitr. Fl. Russi. 165 (1852), et in Mem. Sav. Etrang.Acad. Petersb. 7: 341 (1854). A. sogdiana Bunge, I.c. 167 et I.c. 343: A. maracandic Bunge, I.c. 169, et. I.c. 345. A. fragrans Willd. var. maracandica (Bunge) Bmss., Fl. Or. 366 (1875). A.Herba-alba Asso var. densiflora Bmss., I.c. 365, p.p. A. flavifolia Gilli, Feddes Repert. 68: 94 (1963). Icon.: Tab. 198.

Typus: Inter Teheran et Ispahan, G.A. OLIVIER, G-BOISS!, P!

Plant suffruticose, 40-60 (-80) high, arachnoid- tomentose; glabrous or subglabrous at flowering time. Caudex woody with many heads. Stem with flowers somewhat erect, 30-50 $(-60) \mathrm{cm}$ long, brownish-yellow or greenish-yellow, branched from base or above middle. Leaf on young sterile shoots long petiolate on upper part of stem, 40-50 mm. long, lamina oblong or ovate, bipinnatisect, laciniate leinear, shortly acuminate, 2-4 mm. long, cauline leaves in middle subsessille, oblong, base auriculate dissected, upper leaves linear, entire. Panicula broadly pyramidal, branches 8-20 $(-35) \mathrm{cm}$. long, spreading or oblong erected. Capitulum sessile or short pedicellate, oblong or narrowly ovate, 3-4 mm. long, scattered or remote in narrowly branched inflorescence. Involucral bracts imbricate, outer bracts small, ovate, dorsal surface dense puberulate, inner bracts long, oblong, somewhat glabrous, margin scabrid.

\section{Examined Material}

Turkey. C9 Hakkâri; from Karadağ Mountains to Berçelan Plateau, Step, near road, $1927 \mathrm{~m}$, $37^{\circ} 35464 N, 043^{\circ} 43883 \mathrm{E}, 05.10 .09 .2014$, 04.10.2014 M. Firat 31325, VANF.

\section{Habitat}

Step, near road.

\section{Phenology}

Flowering and fruiting times from OctoberNovember . 


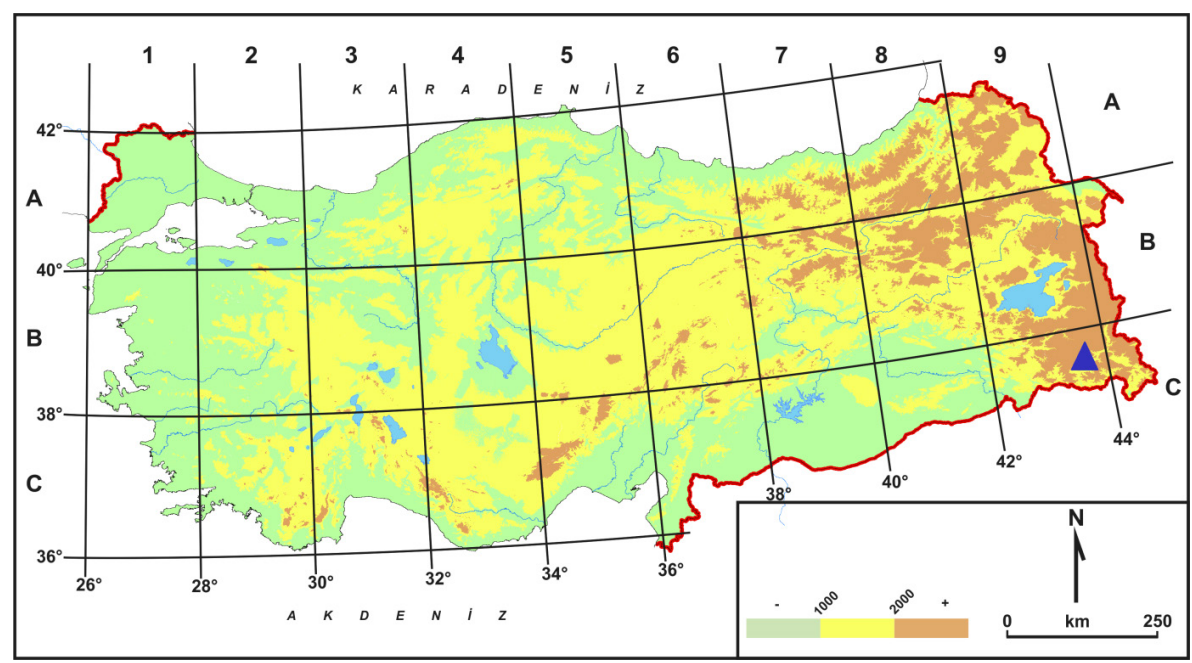

Figure 1. Geographical distribution of Artemisia oliveriana $(\Delta)$ in Turkey.

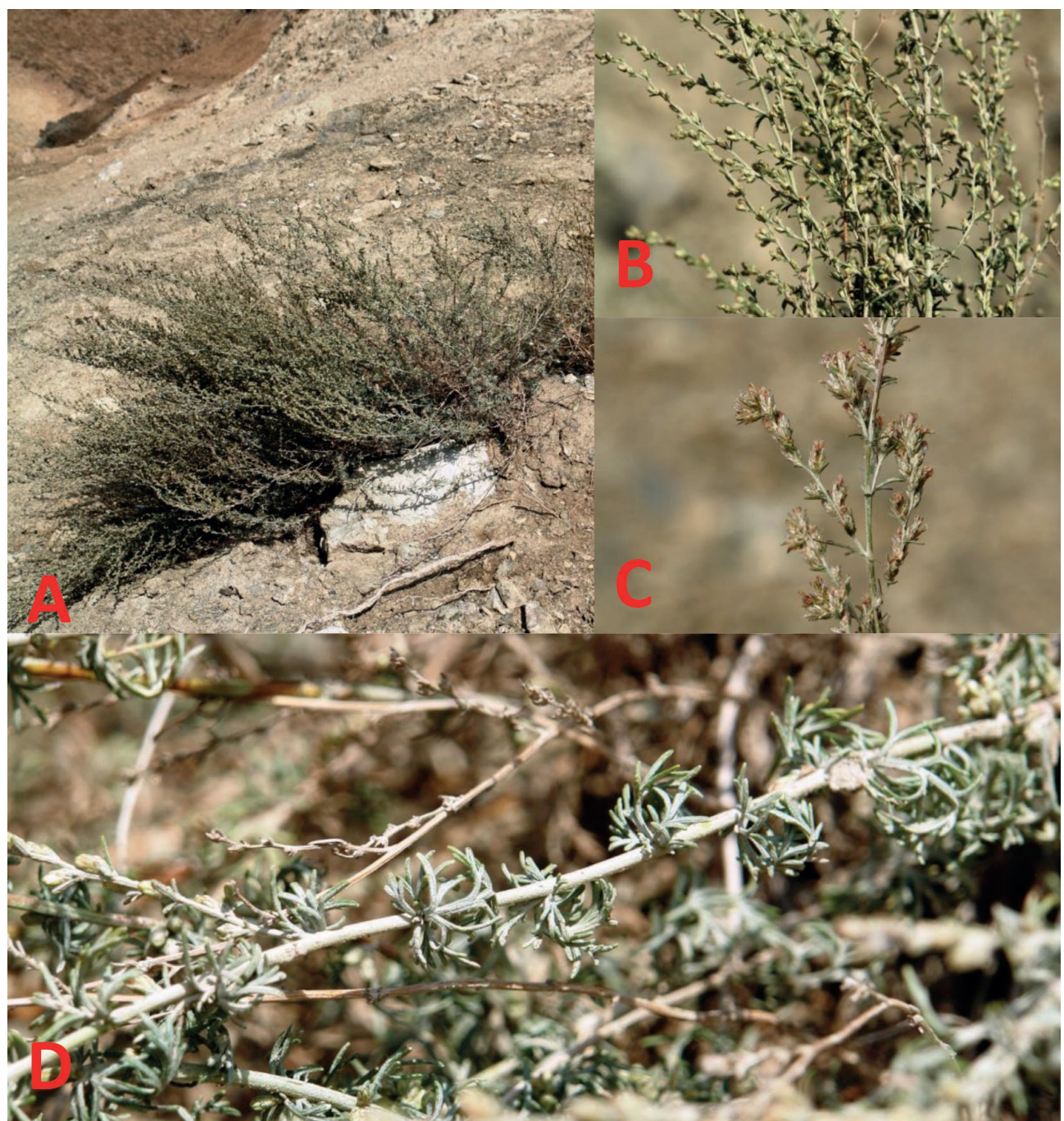

Figure 2. Artemisia oliveriana A. habit and habitat, B-C. General view of the sinflorescence, D. Cauline leaves. 


\section{Distribution in Turkey}

Hakkâri.

\section{General Distribution}

Persia, Turcomania, Afghanistan, Pakistan, Asia centralis.

\section{Vernacular Name}

In Hakkâri province, indigenous people use the name "Hewşan" for Artemisia [22].

\section{RESULTS AND DISCUSSION}

In our country, the genus Artemisia L. is represented by 22 species, 1 subspecies and 2 varieties. One of these 25 taxa is endemic. The number of taxa in our country has risen to 26 with this new record. Thus, this has contributed to both the region of Hakkari where limited information is known about its flora in private and the Flora of Turkey.

\section{ACKNOWLEDGEMENTS}

Thanks to Dr. Ümit Budak for checking new records and thanks Kurtuluş Özgişi for correct English grammer.

\section{References}

1. Y. R. Ling, Th e Old World Seriphidium (Compositae), Bull Bot Res Harbin, 11 (1991) 1-40.

2. Y.R. Ling, The Old World Artemisia (Compositae) Bulletin of Botanical Research Harbin, 12 (1991) 1-10.

3. J. Vallès, S. Šiljak-Yakovlev, Cytogenetic studies in the genus Artemisia L. (Asteraceae): fluorochromebanded karyotypes of five taxa, including the Iberian endemic species Artemisia barrelieri Besser, Canadian Journal of Botany, 75 (1997) 595-606.

4. V.A. Funk, A. Susana, T.F. Stuessy, H.E., Robinson Classification of Compositae, In: V. A. Funk, A. Susana, T.F. Stuessy, R.J. Bayer (eds.), Systematics, Evolution and Biogeography of the Compositae, Vienna: International Association for Plant Taxonomy, (2009), 171-189.

5. J.Vallès, T. Garnatje, S. Garcia, M. Sanz, A. A. Korobkov, Chromosome numbers in the tribes Anthemideae and Inuleae (Asteraceae), Bot. Journal of the Linnean Society, 148 (2005) 77- 85.

6. A. Chehregani, M. Atri, A. Yousefi, F. Jalali Polyploidy variation in some species of the genus Artemisia L. (Asteraceae) in Iran, Caryologia, 63 (2010) 168-175.

7. M.Q. Hayat, M. Ashraf, M.A. Khan, G. Yasmin, N. Shaheen, S. Jabeen, Palynological study of the genus Artemisia (Asteraceae) and its systematics implications, Pakistan Journal of Botany, 42 (2010) 751-763.
8. T. Kawatani, T. Ohno, Chromosome numbers in Artemisia, Bulletin National Institute of Hygienic Sciences, 8 (1964) 183-193.

9. X.J. Vallès, Aportación al conocimiento citotaxanómico de ocho táxones Ibéricos del género Artemisia L. (Asteraceae, Anthemideae), Anales Jardín Botánico de Madrid, 44 (1987) 79-96.

10. E. Gabriellian, X.J. Vallès New data about the genus Artemisia L. (Asteraceae) in Armenia, Willdenowia, 26 (1996) 245-250.

11. M. Torrell, N. Garcia-Jacas, A. Susana, J.Vallès, Infrageneric phylogeny of the genus Artemisia L. (Asteraceae, Anthemideae) based on nucleotide sequences of nuclear ribosomal DNA internal transcribed spacers (ITS), Taxon, 48 (1999) 721-736.

12. M. Torrell, J. Vallès, Genome size in 21 Artemisia L. species (Asteraceae, Anthemideae), systematic, evolutionary, and ecological implications, Genome, 44 (2001) 231-238.

13. M. Torrell, N. Garcia-Jacas, J. Vallès, M. Torrell, V. Mozaffarian, E. Gabrielian, New or rare chromosome counts in the genus Artemisia L. (Asteraceae, Anthemideae) from Armenia and Iran, Botanical Journal of the Linnean Society, 135 (2001) 51-60.

14. J. Valles, M. Torrell, T. Garnatje, N. Garcia-Jacas, R. Vilatersana, A. Susanna, The genus Artemisia and its allies, phylogeny of the subtribe Artemisiinae (Asteraceae, Anthemideae) based on nucleotide sequences of nuclear ribosomal DNA internal transcribed spacers (ITS), Plant Biology, 5 (2003) 274-284.

15. M. Kurşat, Ş. Civelek, I. Türkoğlu, S. Tabur, Artemisia sieberi Bess. subsp. sieberi A new record for Turkey and a delete record for Turkey Artemisia herba-alba Asso. (Asteraceae), Pakistan J. Bot., 43 (2011) 18191821.

16. M. Kurşat M, Artemisia. In: A. Güner, S. Aslan, T. Ekim, M. Vural, M. T. Babaç, (eds.) Türkiye Bitkileri Listesi (Damarlı Bitkiler). İstanbul, Türkiye, Nezahat Gökyiğit Botanik Bahçesi ve Flora Araştırmaları Derneği Yayını, 2012.

17. M. Kurşat, Ş. Civelek, İ. Türkoğlu, S. Tabur, A new subspecies record for the flora of Turkey: Artemisia santonicum L. subsp. patens (Neilr.) K.M.Perss. (Asteraceae), Turk. J. Bot., 35 (2011) 89.

18. M. Kurşat, Ş. Civelek, I. Türkoğlu, S. Tabur, N. Gür, A new species of subgenus Seriphidium of Artemisia L. (Asteraceae) from Turkey, Turkish Journal of Botany, 39 (2015) 88-95.

19. J. Cullen, Artemisia L. In: P. H. Davis(ed.). Flora of Turkey and the East Aegean Islands, Edinburgh Vol. 5, Edinburgh Univ Press, (1975) 311-324.

20. A. Güner, N. Özhatay, T. Ekim, K.H.C. Başer, Flora of Turkey and the East Aegean Islands, vol. 11. Edinburgh University, Press, Edinburgh, (2000) 197-210.

21. D. Podlech, Flora of Iranica, In: Rechinger, K.H., (Ed.), Austria, (1986) 159-224.

22. M. Fırat, Ferhenga Navên Riwekên Bi Kurdî/Kürtçe Bitki Adları Sözlüğü/Dictionary of Plant Names in Kurdish, Kalkan Ofset, Ankara, (2013) 652. 